\title{
CLINICOPATHOLOGIC APPRAISAL OF UTERINE AND CERVICAL POLYPOID LESION IN NORTH WESTERN NIGERIA
}

\author{
Ukwu AE ${ }^{1}$, Shehu $\mathrm{CE}^{1}$, Adoke $\mathrm{AU}^{1}$, Nura $\mathrm{M}^{1}$, Kabiru $\mathrm{A}^{2}$, Umar $\mathrm{M}^{1}$ \\ ${ }^{1}$ Department of Obstetrics and Gynecology and ${ }^{2}$ Department of Pathology \\ Usmanu Danfodiyo University Teaching Hospital, PMB 2370, Sokoto, Sokoto State, Nigeria.
}

Correspondence: Dr. Abdullahi Umar Adoke

Department of Obstetrics and Gynecology, Usmanu Danfodiyo University Teaching Hospital, PMB 2370, Sokoto, Sokoto State, Nigeria E-mail: aadoke@yahoo.com

\section{ABSTRACT}

Background: Uterine and cervical polypoid lesions show varying morphological characteristic ranging from neoplastic to non-neoplastic and inflammatory features. They are a recognized cause of abnormal uterine bleeding among women of reproductive age group and rarely in postmenopausal women.

Objectives: To study the Clinico-pathological aspects of uterine and cervical polypoid lesions and the outcome of their management.

Material and Method: A 10-year retrospective study of all cases of endometrial and cervical polyp who were admitted via Gynecological out-patient department and managed at UDUTH, Sokoto.

Result: During the period of study, polypoid lesion of the uterus and cervix accounted for $1.4 \%$ of Gynecological surgeries. There were $26(81.2 \%)$ cases of cervical polyp and $6(18.8 \%)$ cases of endometrial polyp. The mean age of patient was $37.3 \pm 7.5 y$ rs. The common presenting symptom were protrusion per vagina $18(56.3 \%), 10(31.3 \%)$ had vaginal bleeding and $4(12.5 \%)$ had vaginal discharge. Fibroid polyp $16(50 \%)$ was the commonest histopathologic type seen in this study followed by ectocervical polyp $7(21.9 \%)$ among the cervical polyps. All the lesions were benign.

Conclusion: Polypoid lesion of the endometrium and cervix are not prevalent in our environment. When they occur, thorough evaluation and histopathology studies will help identify the histological type and also rule-out malignancy.

Key word: Cervical polyp

\section{INTRODUCTION}

A $\mathrm{n}$ endometrial/cervical polyp is a common benign polyp or tumor on the surface of the endometrial or cervical canal. Diseases of the cervix are common in young sexually active women. Generally, most polyps are small or average sized; however giant sized polyps have been reported ${ }^{1}$. Non-neoplastic diseases of the cervix are predominantly inflammatory in nature ${ }^{2}$. Even though a cervical polyp is completely benign in nature, there is a $1 \%$ chance that the cervical polyp might show neoplastic change in the future, leading to cervical cancer. However, it has been documented that only about $2 \%$ of cervical polyps undergo malignant transformation ${ }^{3}$.

The cause of cervical polyps is not completely understood. They may occur due to abnormal response to increased levels of the female hormone estrogen, chronic inflammation, clogged blood vessels in the cervix. Chronic granulomatous inflammation also affects the cervix. Worldwide, the commonest granulomatous infection is tuberculosis ${ }^{3}$. Other less frequent causes include schistosomiasis, amoebiasis, enterobiasis, actinomycosis, Iymphogranuloma venerum (LGV) and syphilis.
Schistosomiasis is endemic in the tropics. In severe infections, calcified ova of Schistosoma may be seen in the genital tract. Cervical involvement may be present as polypoid or nodular $\mathrm{m}$ a s se $\mathrm{s}^{4}$. E m b y o $\mathrm{n}$ a I rhabdomyosarcoma of the cervix usually presents as a cervical polyp and sometimes there are multiple polyps. ${ }^{5,6}$

\section{MATERIALS AND METHOD}

This is a retrospective study involving all polypoid lesions of the endometrium and cervix that were assessed at the Histo-pathology department of Usmanu Dan-fodiyo University Teaching Hospital (UDUTH), Sokoto, over a 10 -year period ( $1^{\text {st }}$ January 2004 to $31^{\text {st }}$ December 2013). The UDUTH, Sokoto, is a tertiary health institution located in the North-Western region of the country. The hospital has a residency programme in the sub- 
specialties like Obstetrics and Gynecology, Surgery, Internal Medicine, Public health, Histopathology, General Medicine. The hospital cases were referred from the health institutions in Sokoto metropolis and also from neighboring states like Zamfara, Kebbi, and Niger states. It also obtains referrals from Niger republic, a country located in the northern frontiers of Nigeria. The case notes of patients who were managed for polypoid lesion of the endometrium and cervix during the study period were retrieved from the medical records department. The records were traced to the Histopathology department and Gynecological operation register were extracted and analyzed. Information obtained from the records included the patients' demographic data such as age, place of residence, occupation, parity; presenting complaint, type of surgery, histologic diagnosis were recorded in a study proforma.

All analysis was conducted using SPSS version 20. Data were presented using relevant descriptive statistics.

RESULT During the study period, a total of 2,314 Gynecological surgeries were recorded. There were 32 cases of polyp recorded with 26 cases of cervical polyp and 6 case of endometrial polyp. Endometrial and cervical polypoid lesions accounted for $1.4 \%$ of all gynecologic surgeries. They occur between 25-54yrs and are commonest at $40-44 y$ rs of age. No case was seen before the age of $20 \mathrm{yrs}$ and after the age of 55yrs. Patients with high parity $\geq 3$ constitute $24(75 \%)$ while patients with $\leq 28(25 \%)$. The common clinical features were vaginal bleeding $10(31.2 \%)$, vaginal discharge $6(18.8 \%)$ and protrusion per vaginam $16(50 \%)$. Majority of patients had polypectomy $20(62.5 \%)$ while $12(37.5 \%)$ had total abdominal hysterectomy. Comparism of the sizes of polyp revealed that the smallest sized fibroid was about $4 \times 2 \mathrm{~cm}$ and the largest $10 \times 8 \mathrm{~cm}$. Fibroid polyp was the commonest histopathologic type seen in this study $16(50 \%)$. Histologically, fibroid polyp show sheaths of smooth muscle cells arranged in whorls with surrounding abundant connective tissue. Ectocervical polyp was seen in $7(21.9 \%)$. Histologically, ectocervical polyps are pale, flesh-colored smooth and rounded, often with a broad pedicle. Ectocervical ones are covered by stratified squamous epithelium. The stroma, which contains thick-walled blood vessels at the base and many small vessels in the center, is more fibrous in ectocervical polyps. Endometrial polyp was found in $6(18.8 \%)$ and show $f$ e a $t$ u r e $s$ of numerous glands and blood vessel. Polypoid lesion with predominant fibrosis and epithelial lining were labeled as fibroepithelial polyp 1 ( $3.1 \%)$. Endocervical polyps account for $1(3.1 \%)$ of c a s e s. Histologically, it is composed of loose edematous stroma, few endocervical glands and chronic inflammatory cells consisting predominantly lymphocytes, giant cells and few plasma cells. Endocervical polyps are covered by e $n d$ o c e r v c a l, squamocolumnar or metaplastic squamous epithelium. Adenomatous polyp show glandular component and were seen in $1(3.1 \%)$ of the cases studied

\section{DISCUSSION}

In this study, polypoid endometrial and cervical lesion account for $1.4 \%$ of all gynecologic surgeries in UDUTH Sokoto. It is commonest in women in their $4^{\text {th }}$ decade of life which is in consonance with findings from other studies. ${ }^{7,8,9}$ This study further reaffirms earlier findings that it is a disease of wome $n$ with in the reproductive age. Polypoid lesions are usually small in size $1-2 \mathrm{~cm}$, though in rare

\begin{tabular}{|c|c|c|c|c|c|c|c|}
\hline \multirow[b]{2}{*}{ Histological Type } & \multicolumn{7}{|c|}{ Age group } \\
\hline & $20-24$ & $25-29$ & $30-34$ & $35-39$ & $40-44$ & $45-49$ & $50-54$ \\
\hline Cervical polyp & 0 & 1 & 1 & 1 & 2 & 0 & 2 \\
\hline Fibroid polyp & 0 & 2 & 2 & 1 & 7 & 3 & 1 \\
\hline Endometrial polyp & 0 & 0 & 3 & 2 & 1 & 0 & 0 \\
\hline Fibro epithelial polyp & 0 & 1 & 0 & 0 & 0 & 0 & 0 \\
\hline Endocervical polyp & 0 & 0 & 1 & 0 & 0 & 0 & 0 \\
\hline \multirow[t]{2}{*}{ Adenomatous polyp } & 1 & 0 & 0 & 0 & 0 & 0 & 0 \\
\hline & 1 & 4 & 7 & 4 & 10 & 3 & 3 \\
\hline \multirow{2}{*}{\multicolumn{2}{|c|}{ Histological Type }} & \multicolumn{5}{|c|}{ parity } & \\
\hline & & $0-2$ & & $3-5$ & $=$ & & Total \\
\hline \multicolumn{2}{|l|}{ Cervical polyp } & \multicolumn{2}{|c|}{2} & 3 & 2 & & 7 \\
\hline \multicolumn{2}{|l|}{ Fibroid polyp } & \multicolumn{2}{|c|}{4} & 6 & 6 & & 16 \\
\hline \multicolumn{2}{|c|}{ Endometrial polyp } & \multicolumn{2}{|c|}{1} & 2 & 3 & & 6 \\
\hline \multicolumn{2}{|c|}{ Fibro epithelial polyp } & \multicolumn{2}{|c|}{0} & 1 & 0 & & 1 \\
\hline \multicolumn{2}{|c|}{ Endocervical polyp } & \multicolumn{2}{|c|}{0} & 1 & 0 & & 1 \\
\hline \multicolumn{2}{|c|}{ Adenomatous polyp } & \multicolumn{2}{|c|}{1} & 0 & 0 & & 1 \\
\hline \multicolumn{2}{|l|}{ Total } & \multicolumn{2}{|c|}{8} & 13 & 11 & & 32 \\
\hline
\end{tabular}




\begin{tabular}{lcccc}
\hline Histology type & \multicolumn{3}{c}{ Presenting complaint } & \\
\cline { 2 - 4 } & $\begin{array}{c}\text { Vaginal } \\
\text { bleeding }\end{array}$ & $\begin{array}{c}\text { protrusion per } \\
\text { vaginam }\end{array}$ & $\begin{array}{c}\text { Vaginal } \\
\text { discharge }\end{array}$ & Total \\
\hline Cervical polyp & 2 & 2 & 0 & 4 \\
Fibroid polyp & 2 & 7 & 2 & 11 \\
Endometrial polyp & 1 & 4 & 1 & 6 \\
Fibro epithelial polyp & 0 & 1 & 0 & 1 \\
Endocervical polyp & 4 & 1 & 3 & 8 \\
Adenomatous polyp & 1 & 1 & 0 & 2 \\
$\quad$ Total & 10 & 16 & 6 & 32 \\
\hline
\end{tabular}

situations, polyp may grow to a very large size mimicking malignancy ${ }^{10}$. The largest size of polyp documented in this study was a fibroid polyp measuring $10 \mathrm{~cm} \times 8 \mathrm{~cm} \times 6 \mathrm{~cm}$. Cervical polyps often show no symptoms ${ }^{11}$. Where there are symptoms, they include intermenstrual bleeding, abnormally heavy menstrual bleeding, post-menopausal bleeding women and postcoital bleeding. Other symptoms are vaginal discharge and sensation of vaginal fullness. Protrusion per vagina was the commonest presenting symptom which is a departure from earlier finding of vaginal bleeding ${ }^{12}$.

Endometrial and cervical polyp may be neoplastic or non neoplastic. Rarely, there may be abnormal, precancerous, or cancer cells in a polyp. Among the cases studied, none had neoplastic features. Fibroid polyp was the commonest histopathologic feature we found. This is a departure from previous finding worldwide and the work Sidhalingreddy et al that revealed endocervical polyp to be the commonest ${ }^{12}$. Because fibroid occurs more in blacks' race than in the Caucasians, this could explain the findings in this study.

Routine removal of cervical polyps, although not mandatory, seems clinically prudent because pathological evaluation is needed to confirm the diagnosis and to rule out other possibilities.
Simple polypectomy was offered in majority of cases in this study. However, patients with polyp coexisting with multiple uterine fibroid who had completed their family size were offered total abdominal hysterectomy. This explains the high rate of hysterectomy reported in this study.

\section{CONCLUSION}

Polypoid lesion of the endometrium and cervix are typically non-neoplastic in nature. They tend to be commoner in women within reproductive age group although may occur among postmenopausal women. Most cases are symptomatic and surgery is the main stay of treatment. Thorough evaluation and histopathologic studies will help identify the histological type and rule out the rare possibility of malignancy.

\section{REFERENCES}

1. Abdul M.A, Koledade A.K, Madugu N. Giant cervical polyp complicating uterine fibroid and masquerading as cervical malignancy. Arch Int Surg. 2012; 2:39-41.

2. Olutoyin G Omoniyi-Esan,* Steven A Osasan, and Olusegun $S$ Ojo. Nonneoplastic diseases of the cervix in Nigerians: A histopathological study. Afr Health Sci. 2006; 6(2): 76-80.

3. Khalil A.M, Azar G.B, Kasoar H.G, Abu-Musa A.A, Charara I.R, Seoud M.A. Giant cervical polyp: A case report. J Repod Med 1996; 4:619-21.

4. Tirlapur S.A, Adeyemo A, O'Gorman N, Selo-Ojeme D. Clinico-pathological study of cervical polyps. Arch Gynecol Obstet. 2010; 282(5):535-8.

5. Ghaemmaghami F, Karimi Z.M, Ghasemi M. Lower g e n i t a l $\mathrm{tr}$ a c t rhabdomyosarcoma: Case series and literature review. Arch Gynecol Obstet. 2008; 278:65-9.

6. Ocheke A.N, Umar N.I, Silas O.A, Tanko N.M, Mutihir J.T. E $m$ b $r$ y $\quad$ o $\quad n$ a l rhabdomyosarcoma of the cervix. Afr J Paediatr Surg. 2011; 8:95-7.

7. Pallipady A, Illanthody S, Vaidya R, Ahmed Z, Suvarna $\mathrm{R}$, Metkar $\mathrm{G}$ et al. A ClinicoMorphological spectrum of the Non-neoplastic lesions of the uterine cervix at $\mathrm{AJ}$ Hospital Mangalore. J of Clinic and Diag. Res. 2011; 5: 546-50.

8. Nigatu B, Gebrehiwot Y, Kiros $\mathrm{K}$, Eregete W. A five year analysis of histopathological results of cervical biopsies examined in a pathology department of a teaching hos pital ( 2003 2007).Ethiop.J.Reprod.Healt h. 2010; 4:52-7.

9. Nwachokor F.N,GC Forae. Morphological spectrum of non-neoplastic lesions of the uterine cervix in Warri, South-South, Nigeria. 2013; 16(4) : 429-432

10. Katz V.L. Benign gynecologic lesions. Comprehensive Gynecology. 5th ed. Philadelphia, Pa: Mosby Elsevier; 2007: chap 18.

11. Lowe D, Slavin G. Nonneoplastic conditions of the cervix. In: Fox $\mathrm{H}$, editor. Haines \& Taylor: Obstetrical and Gynecological pathology. 4th edition. Vol. 6. New York: Churchill Livingstone; 1995. pp. 249-267.

12. Sidhalingreddy, Shilpa Biradar, Akhila, V. D. Domble. Clinico-pathologic analysis of polypoid lesions of cervix. JEMDS. 2013. 2278-4748. 